\title{
APLIKASI LAPANG PUPUK HAYATI VP3 DIBANDINGKAN DENGAN EMPAT MACAM PUPUK HAYATI YANG BEREDAR DI PASARAN TERHADAP PRODUKSI TANAMAN KEDELAI (Glycine max L.)
}

\author{
Putri Nur Azizah ${ }^{1}$, Sunawan ${ }^{1}$, Novi Arfarita ${ }^{1^{*}}$ \\ ${ }^{1}$ Departemen Agroteknologi, Fakultas Pertanian, Universitas Islam Malang \\ Jalan MT. Haryono No. 193 Malang 65144, Jawa Timur, Indonesia \\ *Korespondensi: arfarita@unisma.ac.id
}

\begin{abstract}
Abstrak
Penelitian dilakukan untuk mengetahui pengaruh aplikasi pupuk hayati VP3 dibandingkan dengan pupuk hayati yang beredar di pasaran terhadap produksi tanaman kedelai (Glycine max L.) di lapang. Penelitian dilaksanakan di Lahan Perumahan Bumi Asri, Kecamatan Dau, Kabupaten Malang dan Laboratorium Terapan, Fakultas Pertanian, Universitas Islam Malang pada bulan Juni sampai dengan Oktober 2019. Penelitian menggunakan Rancangan Acak Kelompok (RAK) dengan 6 perlakuan yang diulang sebanyak 3 kali. Hasil penelitian menunjukkan bahwa aplikasi pupuk hayati VP3 bila dibandingkan dengan pupuk hayati yang beredar di pasaran memberikan hasil yang lebih baik terhadap parameter pertumbuhan produksi tanaman kedelai di lapang. Hal ini terlihat signifikan pada parameter pertumbuhan luas daun per tanaman, bobot biji total per tanaman, dan bobot biji total per petak.
\end{abstract}

Kata Kunci: Pupuk Hayati VP3, Pupuk Hayati yang beredar dipasaran, Kedelai

\begin{abstract}
Abstrack
The study was undertaken to determine the effect of application VP3 biofertilizer compared to biofertilizers circulating in the market on the production of soybean (Glycine max L.) in the field. The research was conducted on land in Bumi Asri Housing, Dau District, Malang Regency and the Applied Laboratory, Faculty of Agriculture, Malang Islamic University from June to October 2019. The research used a Randomized Block Design (RBD) with 6 treatments and was repeated 3 times. The results showed that the application of VP3 biofertilizer when compared with biofertilizers circulating in the market in general gave better results to the growth and production variables of soybean in the field. This was seen to be especially significant on the growth variable the leaf area per plant, total seed weight per plant, and total seed weight per plot.
\end{abstract}

Keywords: VP3 Biofertilizer, Biofertilizers Circulating in the Market, Soybean

\section{Pendahuluan}

Kedelai (Glycine max L.) merupakan komoditas pertanian penting untuk mendukung kebutuhan pangan nasional. Menurut data Kementerian Perdagangan RI, konsumsi kedelai di Indonesia mencapai 2,25 juta ton/tahun dan kekurangan pasokan kedelai diperoleh dengan impor kedelai dari Amerika (Nugrayasa, 2013). Tingginya impor kedelai mempunyai korelasi dengan rendahnya produksi kedelai di dalam negeri. Rendahnya produksi kedelai ini disebabkan oleh penurunan kesuburan tanah di lahan pertanian akibat penggunaan pupuk anorganik secara berlebihan dalam jangka waktu lama yang berakibat pada menurunnya bahan organik tanah, permeabilitas tanah, 
menurunnya populasi mikroorganisme tanah dan akhirnya tanah menjadi keras (Herdiyanto \& Setiawan, 2015; Roidah, 2013).

Upaya yang dapat dilakukan untuk meningkatkan produksi kedelai dan kesuburan tanah adalah dengan aplikasi pupuk hayati yang ramah lingkungan. Pupuk hayati memiliki fungsi menyuburkan dan memperbaiki struktur tanah, mampu menekan pertumbuhan mikroba pathogen, serta mereduksi penggunaan pupuk anorganik tanpa mengurangi produktivitas tanaman. Saat ini, berbagai macam pupuk hayati telah banyak beredar di pasaran dengan keunggulan masing-masing. Pupuk hayati yang beredar di pasaran biasanya telah diperkaya oleh unsur hara dan hormon pertumbuhan tanaman yang dapat berpengaruh terhadap keefektifan mikroorganisme yang terkandung dalam pupuk hayati (Husen et al., 2007).

Tahap penelitian pupuk hayati VP3 diawali dengan eksplorasi bakteri tanah di daerah Malang dan didapatkan tiga bakteri indigenous yakni bakteri penambat $\mathrm{N}$-free Bacillus licheniformis, bakteri pelarut fosfat Pantoea ananatis, dan bakteri penghasil eksopolisakarida Pseudomonas plecoglossicida (Arfarita et al., 2016; Arfarita et al., 2017; Arfarita et al., 2019). Tahap formulasi pupuk hayati diperoleh dengan menggunakan bahan pembawa vermiwash. Vermiwash merupakan pupuk organik cair yang berasal dari vermikompos yang telah melalui proses fermentasi. VP3 merupakan formulasi pupuk hayati cair yang dibuat dari vermiwash sebagai bahan pembawa, molase, PEG, dan 3 isolat bakteri fungsional (Arfarita, et al., 2020). Pupuk hayati VP3 telah diuji coba pada tanaman buncis, kacang panjang, dan kacang hijau di green house. Namun, aplikasi pupuk hayati VP3 belum diaplikasikan pada tanaman kedelai di lapang yang dibandingkan dengan pupuk hayati yang beredar dipasaran. Oleh karena itu, perlu diketahui pengaruh aplikasi pupuk hayati VP3 bila dibandingkan dengan pupuk hayati yang beredar dipasaran terhadap produksi tanaman kedelai di lapang.

\section{Bahan dan Metode}

Penelitian dilaksanakan pada bulan Juni sampai dengan Oktober 2019 di lahan Perumahan Bumi Asri, Kecamatan Dau, Kabupaten Malang, dan di Laboratorium Terapan Fakultas Pertanian Universitas Islam Malang. Alat-alat yang digunakan antara lain cangkul, gembor, penggaris, label, ajir, timbangan analitik, sprayer, gelas ukur, pengaduk, selang, oven, dan alat tulis. Adapun bahan yang digunakan meliputi lahan yang terbebas dari residu pupuk anorganik dan pestisida, benih kedelai varietas Anjasmoro, kompos, air, fungisida, insektisida, racun siput, furadan, pupuk hayati VP3, pupuk hayati EM4, pupuk hayati Sumber Subur, pupuk hayati Semanggi, dan pupuk hayati Magicgro G6. 
Penelitian ini menggunakan Rancangan Acak Kelompok (RAK) yang terdiri dari 6 perlakuan, yakni TB (Tanah Biasa), TKHA (Tanah + Kompos + Pupuk Hayati VP3), TKPH1 (Tanah + Kompos + Pupuk Hayati EM4), TKPH2 (Tanah + Kompos + Pupuk Hayati Sumber Subur), TKPH3 (Tanah + Kompos + Pupuk Hayati Semanggi), dan TKPH4 (Tanah + Kompos + Pupuk Hayati Magicgro G6) kemudian semua perlakuan diulang sebanyak 3 kali sehingga diperoleh 18 petak perlakuan.

Aplikasi pupuk hayati VP3 dan pupuk hayati yang beredar dipasaran dilakukan sebanyak 3 kali, yakni 1 minggu sebelum tanam, 7 hari setelah tanam (HST), dan 30 hari setelah tanam (HST) dengan dosis $22,5 \mathrm{ml} / 2,25$ liter air per petak pada setiap aplikasi.

Parameter yang diamati meliputi tinggi tanaman, jumlah daun, luas daun per tanaman, bobot kering tajuk dan akar, jumlah bintil akar, total jumlah bunga, total jumlah polong, persentase bunga jadi polong, bobot polong, bobot 100 biji, bobot biji total per tanaman, bobot biji total per petak, dan kandungan NPK tanah.

Data yang diperoleh dianalisis menggunakan analisis statistik dengan uji $\mathrm{F}$ (ANOVA) taraf $5 \%$ serta jika ada pengaruh nyata, maka dilanjutkan uji BNT dengan taraf $5 \%$.

\section{Hasil dan Pembahasan \\ Kandungan NPK Tanah}

Analisis NPK tanah pada penelitian ini dilakukan di laboratorium Universitas Brawijaya (UB) (Tabel 2) yang mengacu pada penilaian sifat kimia tanah (Tabel 1), menunjukkan bahwa kandungan $\mathrm{N}$ total (\%) tanah pada pengamatan 7 HSP (hari setelah perlakuan) dan 100 HST (hari setelah tanam) tergolong dalam kategori rendah, karena berada pada kisaran $0,1-0,2 \%$. Hal ini karena unsur hara nitrogen tidak tersedia di dalam tanah, bersifat mobil dan mudah mengalami perubahan bentuk, sehingga tidak banyak tersedia bagi tanaman (Hanafiah, 2005; Mawardiana dkk., 2013). Ketersediaan nitrogen sangat penting untuk budidaya tanaman kedelai terutama pada saat fase vegetatif (Ohyama et al., 2017). Unsur nitrogen dapat mempercepat pertumbuhan, berperan dalam pembentukan klorofil pada daun yang penting dalam proses fotosintesis, sehingga keberadaan unsur nitrogen sangat dibutuhkan dalam keberlangsungan proses respirasi dan metabolisme tanaman (Islam et al., 2010). Unsur nitrogen diserap tanaman melalui akar dalam bentuk ion-ion $\mathrm{NH}_{4}{ }^{+}$dan $\mathrm{NO}_{3}$. 
Jurnal Folium Vol. 5 No. 1 (2021),26- 41.

E-ISSN 2599-3070, P-ISSN 2656-4572

Tabel 1. Penilaian sifat kimia tanah

\begin{tabular}{|c|c|c|c|c|c|c|}
\hline \multirow{2}{*}{\multicolumn{2}{|c|}{ Parameter Tanah }} & \multicolumn{5}{|c|}{ Nilai } \\
\hline & & $\begin{array}{l}\text { Sangat } \\
\text { Rendah }\end{array}$ & Rendah & Sedang & Tinggi & $\begin{array}{c}\text { Sangat } \\
\text { Tinggi }\end{array}$ \\
\hline $\mathrm{C}(\%)$ & & $<1$ & $1-2$ & $2-3$ & $3-5$ & $>5$ \\
\hline $\mathrm{N}(\%)$ & & $<0.1$ & $0.1-0.2$ & $0.21-0.5$ & $0.51-0.75$ & $>0.75$ \\
\hline $\mathrm{C} / \mathrm{N}$ & & $<5$ & $5-10$ & $11-15$ & $16-25$ & $>25$ \\
\hline $\mathrm{P}_{2} \mathrm{O}_{5} \mathrm{HCl} 25 \%(\mathrm{mg} / 100 \mathrm{~g})$ & & $<15$ & $15-20$ & $21-40$ & $41-60$ & $>60$ \\
\hline $\mathrm{P}_{2} \mathrm{O}_{5}$ Bray $(\mathrm{ppm} \mathrm{P})$ & & $<4$ & $5-7$ & $8-10$ & $11-15$ & $>15$ \\
\hline $\mathrm{P}_{2} \mathrm{O}_{5}$ Olsen (ppm $\mathrm{P}$ ) & & $<5$ & $5-10$ & $11-15$ & $16-20$ & $>20$ \\
\hline $\mathrm{K}_{2} \mathrm{O} \mathrm{HCl} 25 \%(\mathrm{mg} / 100 \mathrm{~g})$ & & $<10$ & $10-20$ & $21-40$ & $41-60$ & $>60$ \\
\hline KTK/CEC (me/100g tanah) & & $<5$ & $5-16$ & $17-24$ & $25-40$ & $>40$ \\
\hline Susunan Kation & & & & & & \\
\hline $\mathrm{Ca}(\mathrm{me} / 100 \mathrm{~g}$ tanah) & & $<2$ & $2-5$ & $6-10$ & $11-20$ & $>20$ \\
\hline $\mathrm{Mg}$ (me/100 g tanah) & & $<0.3$ & $0.4-1$ & $1.1-2.0$ & $2.1-8.0$ & $>8$ \\
\hline $\mathrm{K}$ (me/100 g tanah) & & $<0.1$ & $0.1-0.3$ & $0.4-0.5$ & $0.6-1.0$ & $>1$ \\
\hline $\mathrm{Na}(\mathrm{me} / 100 \mathrm{~g}$ tanah) & & $<0.1$ & $0.1-0.3$ & $0.4-0.7$ & $0.8-1.0$ & $>1$ \\
\hline Kejenuhan Basa (\%) & & $<20$ & $20-40$ & $41-60$ & $61-80$ & $>80$ \\
\hline Kejenuhan Alumunium (\%) & & $<5$ & $5-10$ & $11-20$ & $20-40$ & $>40$ \\
\hline Cadangan Mineral (\%) & & $<5$ & $5-10$ & $11-20$ & $20-40$ & $>40$ \\
\hline Salinitas/DHL (dS/m) & & $<1$ & $1-2$ & $2-3$ & $3-4$ & $>4$ \\
\hline $\begin{array}{ll}\text { Persentase } & \text { natrium } \\
\text { tukar/ESP (\%) }\end{array}$ & dapat & $<2$ & $2-3$ & $5-10$ & $10-15$ & $>15$ \\
\hline
\end{tabular}

Sumber: Eviati \& Sulaeman (BPT), 2009.

Tabel 2. Kadar Hara NPK Tanah

\begin{tabular}{|c|c|c|c|c|c|c|}
\hline \multirow{3}{*}{ Perlakuan } & \multicolumn{6}{|c|}{ Kadar hara NPK tanah } \\
\hline & \multicolumn{3}{|c|}{$0 \mathrm{HSP}$} & \multicolumn{3}{|c|}{$100 \mathrm{HST}$} \\
\hline & $\begin{array}{c}\text { N.total } \\
(\%)\end{array}$ & $\begin{array}{l}\text { P.Bray } 1 \\
\text { (ppm P) }\end{array}$ & $\begin{array}{c}\mathrm{K} \\
(\mathrm{me} / 100 \mathrm{~g})\end{array}$ & $\begin{array}{c}\text { N.total } \\
(\%)\end{array}$ & $\begin{array}{l}\text { P.Bray } 1 \\
\text { (ppm P) }\end{array}$ & $\begin{array}{c}\mathrm{K} \\
(\mathrm{me} / 100 \mathrm{~g})\end{array}$ \\
\hline \multirow{2}{*}{ TB } & 0.16 & 6.16 & 0.74 & 0.15 & 5.97 & 0.48 \\
\hline & $\mathrm{R}$ & $\mathrm{R}$ & $\mathrm{T}$ & $\mathrm{R}$ & $\mathrm{R}$ & $S$ \\
\hline \multirow{2}{*}{ TKHA } & 0.19 & 59.46 & 1.54 & 0.19 & 42.52 & 1.58 \\
\hline & $\mathrm{R}$ & ST & ST & $\mathrm{R}$ & ST & ST \\
\hline \multirow{2}{*}{ TKPH1 } & 0.17 & 22.71 & 1.12 & 0.19 & 54.12 & 1.01 \\
\hline & $\mathrm{R}$ & ST & ST & $\mathrm{R}$ & ST & ST \\
\hline \multirow{2}{*}{ TKPH2 } & 0.18 & 31.47 & 1.29 & 0.19 & 38.63 & 1.24 \\
\hline & $\mathrm{R}$ & ST & ST & $\mathrm{R}$ & ST & ST \\
\hline \multirow{2}{*}{ TKPH3 } & 0.18 & 21.90 & 1.20 & 0.18 & 33.96 & 0.98 \\
\hline & $\mathrm{R}$ & ST & ST & $\mathrm{R}$ & ST & $\mathrm{T}$ \\
\hline \multirow{2}{*}{ TKPH4 } & 0.17 & 16.52 & 1.15 & 0.20 & 44.48 & 1.38 \\
\hline & $\mathrm{R}$ & ST & ST & $\mathrm{R}$ & ST & ST \\
\hline
\end{tabular}

Keterangan: $\mathrm{R}=$ Rendah; $\mathrm{S}=$ Sedang; $\mathrm{T}=$ Tinggi; $\mathrm{ST}=$ Sangat Tinggi. HSP = Hari Setelah Perlakuan; HST = Hari Setelah Tanam.

Kandungan P Bray 1 (ppm P) pada 7 HSP (hari setelah perlakuan) dan 100 HST (hari setelah tanam) menunjukkan bahwa perlakuan TB (Tanah Biasa) berada pada kategori rendah karena berada pada kisaran 5-7 ppm $\mathrm{P}$, sedangkan pada perlakuan pemberian pupuk hayati berada pada kategori sangat tinggi karena nilainya $>15$ ppm P. Nilai kandungan $\mathrm{K}(\mathrm{me} / 100 \mathrm{~g})$ di dalam tanah juga tergolong dalam kategori sangat tinggi karena nilainya $>1 \mathrm{me} / 100 \mathrm{~g}$, kecuali pada perlakuan TB (Tanah Biasa) tergolong tinggi karena berada pada kisaran 0,6-1,0 me/100g. Namun, pada hasil analisis 
sampel tanah umur 100 HST, perlakuan TB (Tanah Biasa) menjadi kategori sedang karena berada pada kisaran 0,4-0,5 me/100g dan perlakuan TKPH3 menjadi kategori tinggi karena berada pada kisaran 0,6-1,0 me/100g.

Nilai kandungan $\mathrm{P}$ dan $\mathrm{K}$ di dalam tanah menunjukkan nilai yang sangat baik, karena semua perlakuan dengan pemberian pupuk hayati tergolong dalam kategori sangat tinggi, sehingga kebutuhan tanaman akan unsur $\mathrm{P}$ dan $\mathrm{K}$ dapat terpenuhi dengan baik. Meskipun pada pengambilan sampel tanah setelah panen mengalami penurunan kandungan $\mathrm{P}$ dan $\mathrm{K}$ pada sebagian perlakuan, namun masih tergolong cukup tersedia bagi tanaman. Ketersediaan unsur $\mathrm{P}$ dan $\mathrm{K}$ ini disebabkan karena pupuk hayati mengandung bakteri pelarut $P$ yang berpotensi dalam melarutkan unsur $\mathrm{P}$ dan $\mathrm{K}$ di dalam tanah. Menurut Kartikawati dkk., (2017), pupuk hayati mampu meningkatkan ketersediaan unsur hara tanaman di dalam tanah dikarenakan adanya mikroorganisme yang melakukan dekomposisi dan mineralisasi hara dari unsur anorganik menjaadi unsur organik, serta memperbaiki sifat fisik tanah.

\section{Tinggi Tanaman}

Pada wal pertumbuhan tanaman kedelai, yakni umur 14 hari setelah tanam (HST) perlakuan yang diaplikasikan pupuk hayati VP3 dan pupuk hayati yang beredar dipasaran tidak berpengaruh nyata terhadap tinggi tanaman (Tabel 3).

Tabel 3. Rata-rata tinggi tanaman kedelai pada perlakuan pupuk hayati VP3 dan pupuk hayati yang beredar dipasaran

\begin{tabular}{ccccccccc}
\hline \multirow{2}{*}{ Perlakuan } & \multicolumn{7}{c}{ Rata-Rata tinggi tanaman (cm) pada umur tanaman (HST) } \\
\cline { 2 - 9 } & 14 & 21 & 28 & 35 & 42 & 49 & 56 & 63 \\
\hline TB & 1.64 & $3.77 \mathrm{a}$ & $7.01 \mathrm{a}$ & $12.36 \mathrm{a}$ & $19.87 \mathrm{a}$ & $29.36 \mathrm{a}$ & $39.64 \mathrm{a}$ & $50.40 \mathrm{a}$ \\
TKHA & 1.94 & $4.84 \mathrm{~b}$ & $8.22 \mathrm{~b}$ & $13.47 \mathrm{ab}$ & $20.99 \mathrm{ab}$ & $32.18 \mathrm{ab}$ & $44.90 \mathrm{ab}$ & $52.63 \mathrm{ab}$ \\
TKPH1 & 1.92 & $4.99 \mathrm{~b}$ & $9.07 \mathrm{~b}$ & $15.34 \mathrm{~b}$ & $23.97 \mathrm{~b}$ & $36.06 \mathrm{~b}$ & $49.01 \mathrm{~b}$ & $59.11 \mathrm{c}$ \\
TKPH2 & 1.87 & $5.23 \mathrm{~b}$ & $9.27 \mathrm{~b}$ & $14.91 \mathrm{~b}$ & $23.05 \mathrm{~b}$ & $34.88 \mathrm{~b}$ & $45.77 \mathrm{ab}$ & $57.94 \mathrm{bc}$ \\
TKPH3 & 1.79 & $4.62 \mathrm{~b}$ & $8.46 \mathrm{~b}$ & $14.22 \mathrm{ab}$ & $22.94 \mathrm{ab}$ & $33.05 \mathrm{ab}$ & $47.36 \mathrm{~b}$ & $57.99 \mathrm{bc}$ \\
TKPH4 & 1.76 & $5.78 \mathrm{~b}$ & $8.22 \mathrm{~b}$ & $13.67 \mathrm{ab}$ & $21.29 \mathrm{ab}$ & $34.16 \mathrm{~b}$ & $47.45 \mathrm{~b}$ & $57.40 \mathrm{bc}$ \\
\hline BNT 5\% & TN & 0.74 & 1.15 & 1.89 & 3.00 & 4.74 & 6.50 & 6.17 \\
\hline
\end{tabular}

Keterangan:Angka yang didampingi dengan notasi yang sama pada kolom yang sama menunjukkan hasil tidak berbeda nyata dengan uji BNT 5\%; TN = Tidak Nyata; HST $=$ Hari Setelah Tanam.

Kondisi ini dikarenakan unsur hara yang dibutuhkan masih dapat dipenuhi oleh kotiledon, sehingga belum terdapat adanya pengaruh dari masing-masing perlakuan. Perbedaan tinggi tanaman yang berbeda nyata mulai terlihat ketika tanaman berumur 21 hari setelah tanam (HST). Pada umur ini, perlakuan TKPH2 (Tanah + Kompos + Pupuk Hayati Sumber Subur) memberikan pengaruh tertinggi dalam meningkatkan tinggi tanaman, namun tidak berbeda nyata bila dibandingkan dengan perlakuan 
pemberian pupuk hayati lainnya. Perakaran pada umur ini sudah mulai aktif begitupun pada bintil akar yang sudah mulai efektif dalam mengikat nitrogen dari udara.

Pada saat tanaman berumur 63 hari setelah tanam (HST) perlakuan TKPH1 (Tanah + Kompos + Pupuk Hayati EM4) memberikan tinggi tanaman yang tidak berbeda nyata dengan perlakuan TKPH2 (Tanah + Kompos + Pupuk Hayati Sumber Subur), TKPH3 (Tanah + Kompos + Pupuk Hayati Semanggi), dan TKPH4 (Tanah + Kompos + Pupuk Hayati Magicgro G6). Hal ini dikarenakan adanya pupuk hayati yang beredar dipasaran mengandung unsur hara makro dan mikro, seperti $\mathrm{N}, \mathrm{P}, \mathrm{K}, \mathrm{Fe}, \mathrm{Cu}$, $\mathrm{Zn}, \mathrm{B}, \mathrm{Cl}$ serta mengandung hormon pertumbuhan tanaman seperti giberelin, sitokinin, dan IAA yang dapat merangsang pertumbuhan tanaman.

\section{Jumlah Daun}

Jumlah daun tanaman kedelai juga mengalami peningkatan seiring dengan adanya pertumbuhan umur tanaman kedelai. Awal pertumbuhan (14 dan 28 HST) yang diaplikasikan pupuk hayati VP3 dan pupuk hayati yang beredar dipasaran tidak berpengaruh nyata terhadap jumlah daun tanaman kedelai (Tabel 4). Keadaan ini disebabkan tanaman kedelai membutuhkan adaptasi dalam memenuhi kebutuhan hara di awal pertumbuhannya, terutama unsur nitrogen yang berguna untuk mendukung pertumbuhan akar tanaman kedelai. Sebagaimana dijelaskan oleh Bachtiar dkk., (2016), bahwa respon akar tanaman terhadap kondisi daerah perakaran dapat menentukan pertumbuhan dan mempengaruhi produktivitas tanaman kedelai.

Tabel 4. Rata-rata jumlah daun tanaman kedelai pada perlakuan pupuk hayati VP3 dan pupuk hayati yang beredar dipasaran

\begin{tabular}{ccccccccc}
\hline \multirow{2}{*}{ Perlakuan } & \multicolumn{7}{c}{ Rata-Rata Jumlah Daun (Helai) Pada Umur Tanaman (HST) } \\
\cline { 2 - 9 } & 14 & 21 & 28 & 35 & 42 & 49 & 56 & 63 \\
\hline TB & 1.56 & $5.15 \mathrm{ab}$ & 9.00 & $13.59 \mathrm{a}$ & $19.19 \mathrm{a}$ & $29.59 \mathrm{a}$ & $50.52 \mathrm{a}$ & $57.33 \mathrm{a}$ \\
TKHA & 1.56 & $5.70 \mathrm{ab}$ & 9.44 & $13.78 \mathrm{a}$ & $19.74 \mathrm{a}$ & $35.00 \mathrm{ab}$ & $55.78 \mathrm{ab}$ & $69.22 \mathrm{~b}$ \\
TKPH1 & 1.67 & $5.70 \mathrm{ab}$ & 10.00 & $15.48 \mathrm{~b}$ & $23.15 \mathrm{~b}$ & $38.74 \mathrm{~b}$ & $61.19 \mathrm{~b}$ & $73.67 \mathrm{~b}$ \\
TKPH2 & 1.67 & $5.96 \mathrm{~b}$ & 9.93 & $14.07 \mathrm{a}$ & $21.22 \mathrm{ab}$ & $37.22 \mathrm{~b}$ & $60.22 \mathrm{ab}$ & $70.59 \mathrm{~b}$ \\
TKPH3 & 1.67 & $4.89 \mathrm{a}$ & 9.74 & $13.56 \mathrm{a}$ & $21.04 \mathrm{ab}$ & $37.22 \mathrm{~b}$ & $52.96 \mathrm{ab}$ & $66.33 \mathrm{ab}$ \\
TKPH4 & 1.67 & $5.89 \mathrm{~b}$ & 10.00 & $13.52 \mathrm{a}$ & $20.07 \mathrm{a}$ & $35.74 \mathrm{ab}$ & $56.74 \mathrm{ab}$ & $70.67 \mathrm{~b}$ \\
\hline BNT 5\% & TN & 0.82 & TN & 1.39 & 2.95 & 6.21 & 10.49 & 11.74 \\
\hline Keterangan & Angka yang didampingi dengan notasi yang & sama pada kolom yang sama \\
menunjukkan hasil tidak berbeda nyata dengan uji BNT 5\%; TN = Tidak Nyata; HST \\
= Hari Setelah Tanam.
\end{tabular}

Saat tanaman berumur 63 hari setelah tanam (HST) perlakuan TKPH1 (Tanah + Kompos + Pupuk Hayati EM4) memberikan jumlah daun yang tidak berbeda nyata dengan perlakuan TKHA (Tanah + Kompos + Pupuk Hayati VP3), TKPH2 (Tanah + Kompos + Pupuk Hayati Sumber Subur), TKPH3 (Tanah + Kompos + Pupuk Hayati 
Semanggi), dan TKPH4 (Tanah + Kompos + Pupuk Hayati Magicgro G6). Pemberian pupuk hayati VP3 dan pupuk hayati yang beredar dipasaran memberikan dampak yang lebih baik bila dibandingkan dengan perlakuan tanpa pemberian pupuk hayati (TB = Tanah Biasa). Hal ini karena pupuk hayati mampu meningkatkan unsur hara di dalam tanah dan mendukung pertumbuhan tanaman melalui aktivitas mikroba yang terkandung dalam pupuk hayati. Menurut Fadiluddin (2009), bahwa mikroba yang terkandung dalam pupuk hayati mampu memfiksasi nitrogen di udara, melarutkan fosfat, dan meningkatkan akses tanaman dalam meningkatkan ketersediaan unsur hara.

\section{Luas Daun Per Tanaman}

Hasil analisis ragam dan uji BNT 5\% pengaruh pemberian pupuk hayati VP3 dan pupuk hayati yang beredar dipasaran berpengaruh nyata terhadap luas daun per tanaman kedelai (Tabel 5). Perlakuan TKHA (Tanah + Kompos + Pupuk Hayati VP3) memberikan luas daun yang tidak berbeda nyata dengan perlakuan TKPH1 (Tanah + Kompos + Pupuk Hayati EM4) dan TKPH4 (Tanah + Kompos + Pupuk Hayati Magicgro G6). Hal ini mengindikasikan bahwa pupuk hayati VP3 mampu memberikan luas daun per tanaman lebih baik, karena pupuk hayati VP3 yang diaplikasikan pada media tanam masih dalam kondisi fresh dan hanya mengandung tiga mikroba indigenous dengan bahan pembawa vermiwash, salah satu bakterinya adalah Bacillus licheniformis yang diketahui mampu memfiksasi nitrogen dari udara tanpa harus bersimbiosis dengan tanaman (Arfarita et al., 2019).

Tabel 5. Rata-rata luas daun per tanaman kedelai pada perlakuan pupuk hayati VP3 dan pupuk hayati yang beredar dipasaran

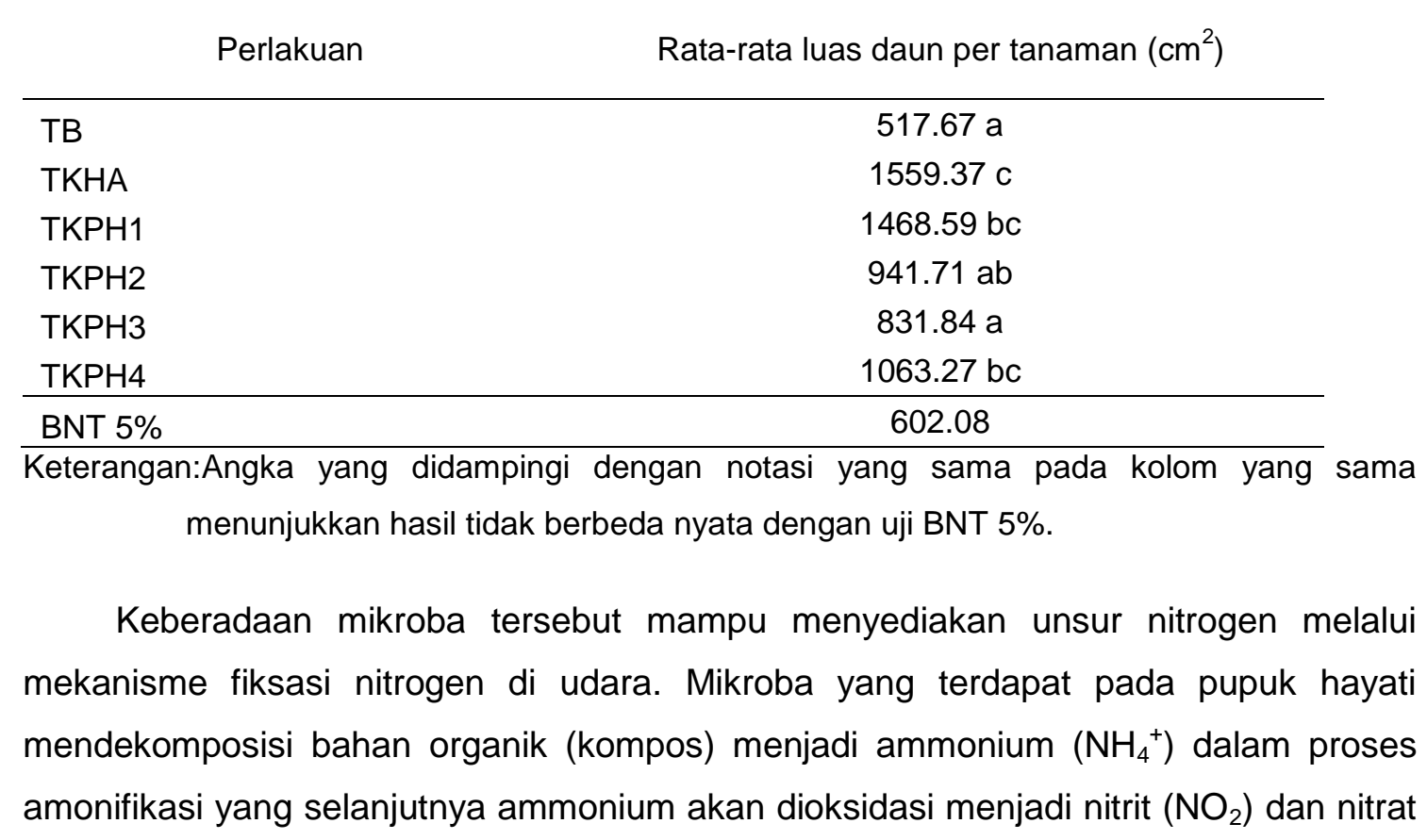


$\left(\mathrm{NO}_{3}{ }^{-}\right)$dalam proses nitrifikasi, sehingga nitrogen dapat diserap oleh tanaman untuk mendukung pertumbuhan luas daun. Apabila unsur $\mathrm{N}$ cukup tersedia bagi tanaman maka kandungan klorofil pada daun akan meningkat dan proses fotosintesis juga meningkat sehingga asimilat yang dihasilkan lebih banyak yang mengakibatkan pertumbuhan tanaman menjadi lebih baik (Tania \& Budi, 2012).

\section{Bobot Kering Tajuk dan Akar}

Bobot kering tanaman merupakan akumulasi hasil fotosintat selama proses pertumbuhan dan perkembangan tanaman, sehingga semakin tinggi bobot kering tanaman maka akan semakin baik pertumbuhan tanaman tersebut. Bobot kering tanaman seringkali berkaitan dengan hara yang diserap oleh tanaman.

Data pengamatan pemberian pupuk hayati VP3 dan pupuk hayati yang beredar dipasaran tidak berpengaruh nyata terhadap parameter bobot kering akar tanaman kedelai (Tabel 6). Hal ini dikarenakan penelitian dilakukan di puncak musim kemarau dengan suhu harian rata-rata $33^{\circ} \mathrm{C}$ yang menyebabkan kondisi petakan tanaman mengalami penurunan kelembaban tanah. Selain itu, volume penyimaran yang diaplikasikan pada setiap petakan diduga masih belum mampu memenuhi kebutuhan tanaman dan juga belum mampu memberikan kondisi lingkungan yang optimal bagi mikroorganisme yang ada di dalam tanah. Sebagaimana dijelaskan oleh Maryani (2012) bahwa bila tanaman kekurangan air maka fotosintat yang dihasilkan tanaman akan dirombak untuk mensintesis senyawa organik terlarut guna menurunkan potensial osmotik sel, sehingga dapat menyebabkan penurunan bobot kering tanaman.

Tabel 6. Rata-rata bobot kering tajuk dan akar tanaman kedelai pada perlakuan pupuk hayati VP3 dan pupuk hayati yang beredar dipasaran

\begin{tabular}{lccc}
\hline \multirow{2}{*}{ Perlakuan } & \multicolumn{3}{c}{ Rata-rata bobot kering tajuk dan akar (gram) } \\
\cline { 2 - 4 } & Batang & Daun & Akar \\
\hline TB & $6.93 \mathrm{a}$ & $3.17 \mathrm{ab}$ & 2.94 \\
TKHA & $8.93 \mathrm{ab}$ & $4.74 \mathrm{bc}$ & 3.15 \\
TKPH1 & $7.59 \mathrm{ab}$ & $2.06 \mathrm{a}$ & 3.18 \\
TKPH2 & $10.47 \mathrm{~b}$ & $6.00 \mathrm{c}$ & 3.21 \\
TKPH3 & $7.96 \mathrm{ab}$ & $3.83 \mathrm{ab}$ & 2.95 \\
TKPH4 & $9.94 \mathrm{~b}$ & $4.96 \mathrm{bc}$ & 3.35 \\
\hline BNT 5\% & 2.91 & 1.95 & TN \\
\hline Keterangan:Angka yang didampingi dengan notasi yang sama pada kolom yang sama &
\end{tabular}

Namun, pemberian pupuk hayati VP3 dan pupuk hayati yang beredar dipasaran memberikan pengaruh nyata terhadap bobot kering tajuk tanaman kedelai. Pada bobot kering batang tanaman kedelai terbaik diperlihatkan oleh perlakuan TKPH2 (Tanah + Kompos + Pupuk Hayati Sumber Subur) yang tidak berbeda nyata dengan perlakuan 
TKHA (Tanah + Kompos + Pupuk Hayati VP3), TKPH1 (Tanah + Kompos + Pupuk Hayati EM4), TKPH3 (Tanah + Kompos + Pupuk Hayati Semanggi), dan TKPH4 (Tanah + Kompos + Pupuk Hayati Magicgro G6). Selanjutnya, pada bobot kering daun tanaman kedelai perlakuan TKPH2 (Tanah + Kompos + Pupuk Hayati Subur) memperlihatkan hasil yang tidak berbeda nyata dengan perlakuan TKPH1 (Tanah + Kompos + Pupuk Hayati EM4) dan TKPH4 (Tanah + Kompos + Pupuk Hayati Magicgro G6). Hal ini menunjukkan bahwa pemberian pupuk hayati mampu memberikan dampak positif terhadap pertumbuhan tanaman yang tercermin pada bobot kering tajuk tanaman kedelai.

Peningkatan bobot kering tajuk tanaman kedelai disebabkan oleh mikroba yang terkandung dalam pupuk hayati, seperti bakteri penambat $\mathrm{N}$ dan pelarut $\mathrm{P}$. Menurut Lakitan (2013), nitrogen bebas yang difiksasi secara hayati akan membantu meningkatkan fotosintesis, selanjutnya hasil fotosintat yang berupa karbohidrat akan ditranslokasikan ke seluruh jaringan tanaman yang akan digunakan dalam mendukung pertumbuhan dan perkembangan tanaman. Selain itu, unsur hara $P$ yang berfungsi pada fase generatif dan Kalium yang membantu pembentuan protein dan karbohidrat, mengeraskan bagian batang tanaman (Apriliani $d k k ., 2016)$.

\section{Jumlah Bintil Akar}

Hasil analisis ragam dan uji BNT 5\% (Tabel 7) menunjukkan bahwa pemberian pupuk hayati VP3 dan pupuk hayati yang beredar dipasaran tidak berpengaruh nyata terhadap jumlah bintil akar tanaman kedelai.

Tabel 7. Rata-rata jumlah bintil akar tanaman kedelai pada perlakuan pupuk hayati VP3 dan pupuk hayati yang beredar dipasaran

\begin{tabular}{|c|c|}
\hline Perlakuan & Rata-Rata Jumlah Bintil Akar (Buah) \\
\hline TB & 44.74 \\
\hline TKHA & 46.67 \\
\hline TKPH1 & 58.70 \\
\hline TKPH2 & 56.11 \\
\hline TKPH3 & 54.48 \\
\hline TKPH4 & 54.56 \\
\hline BNT 5\% & TN \\
\hline
\end{tabular}

Keterangan: TN: Tidak Nyata.

Jumlah bintil akar yang terbentuk sangat dipengaruhi oleh interaksi antara bakteri Rhizobium, tanaman inang dan lingkungan. Faktor lingkungan seperti suhu dan kelembaban tanah sangat berperan dalam kelangsungan hidup bakteri Rhizobium (Novriani, 2011). Hal ini didasarkan pada sebagian besar sel Rhizobium tersusun dari air, sehingga kelembaban tanah merupakan faktor yang penting dalam perkembangan 
Rhizobium di dalam tanah. Keberhasilan inokulasi pupuk hayati tergantung pada keefektifan dan efisiensi dari inokulan yang terkandung dalam pupuk hayati dan memiliki keserasian dengan tanaman inang. Selain itu, tidak munculnya respon pupuk hayati dalam pembentukan bintil akar tanaman kedelai diduga disebabkan oleh kebutuhan $\mathrm{N}$ tanaman kedelai telah tercukupi yang ditandai dengan warna daun yang lebih hijau, sehingga bila kandungan $\mathrm{N}$ tinggi di dalam tanah maka dapat menggagalkan pembentukan bintil akar (Pieter \& Mejaya, 2018; Saragih et al., 2016).

\section{Total Jumlah Bunga, Polong dan Persentase Bunga Jadi Polong}

Berdasarkan hasil penelitian (Tabel 8) menunjukkan bahwa aplikasi pupuk hayati VP3 dan pupuk hayati yang beredar dipasaran dipengaruhi nyata terhadap total jumlah bunga, namun tidak berpengaruh nyata terhadap total jumlah polong kedelai dan persentase bunga jadi polong.

Perlakuan TKPH1 (Tanah + Kompos + Pupuk Hayati EM4) memberikan total jumlah bunga yang lebih baik, namun tidak berbeda nyata dengan perlakuan TKPH2 (Tanah + Kompos + Pupuk Hayati Sumber Subur). Hal ini karena pupuk hayati yang beredar dipasaran mengandung bakteri pelarut $P$ dan telah mengandung unsur hara makro, mikro, serta hormon petumbuhan yang dapat merangsang pertumbuhan dan perkembangan tanaman. Namun, tambahan unsur hara dan hormon pertumbuhan pada pupuk hayati dapat menjadi masalah yang penting, karena dapat menyembunyikan efek utama dari inokulan yang terdapat dalam pupuk hayati (Husen et al., 2007).

Tabel 8. Rata-rata total jumlah bunga, polong dan persentase bunga jadi polong tanaman kedelai pada perlakuan pupuk hayati VP3 dan pupuk hayati yang beredar dipasaran

\begin{tabular}{lccc}
\hline \multirow{2}{*}{ Perlakaun } & \multicolumn{2}{c}{ Rata-rata total jumlah bunga, polong dan persentase bunga jadi polong } \\
\cline { 2 - 4 } & Bunga (Kuntum) & $\begin{array}{c}\text { Polong } \\
\text { (Buah) }\end{array}$ & Persentase Bunga Jadi Polong (\%) \\
\hline TB & $89.15 \mathrm{a}$ & 61.96 & 72.99 \\
TKHA & $96.22 \mathrm{a}$ & 72.93 & 75.58 \\
TKPH1 & $112.41 \mathrm{~b}$ & 69.96 & 63.77 \\
TKPH2 & $103.26 \mathrm{ab}$ & 78.04 & 74.95 \\
TKPH3 & $91.78 \mathrm{a}$ & 66.44 & 70.74 \\
TKPH4 & $91.22 \mathrm{a}$ & 71.33 & 82.96 \\
\hline
\end{tabular}

BNT 5\% $15.43 \quad$ TN

Keterangan: Angka yang didampingi dengan notasi yang sama pada kolom yang sama menunjukkan hasil tidak berbeda nyata dengan uji BNT 5\%; TN: Tidak Nyata.

Jumlah polong tanaman kedelai yang terbentuk akan meningkat seiring dengan bertambahnya jumlah bunga yang terbentuk dan umur tanaman. Rata-rata total jumlah polong tanaman kedelai berkisar antara 61,96-78,04 buah. Hal ini diduga karena unsur $\mathrm{P}$ dan $\mathrm{K}$ yang sangat berperan pada fase generatif tersedia dengan baik di dalam 
tanah (Tabel 2), sehingga kebutuhan tanaman atas unsur hara tersebut dapat terpenuhi. Dimana unsur $P$ ini berperan aktif dalam proses pembentukan bunga, pembuahan, serta pematangan biji dan buah, sedangkan unsur $\mathrm{K}$ berperan dalam prose pembentukan dan pengisian polong (Farianti dkk., 2018). Pupuk hayati yang diaplikasikan ke media tanam secara umum mengandung bakteri pelarut fosfat, salah satunya adalah bakteri Pantoea ananatis yang terdapat pada pupuk hayati VP3. Bakteri pelarut fosfat ini merupakan mikroorganisme yang mampu melepaskan $\mathrm{P}$ tidak larut pada batuan di dalam tanah sehingga ion $\mathrm{P}\left(\mathrm{H}_{2} \mathrm{PO}_{4}^{-}\right.$atau $\left.\mathrm{HPO}_{4}{ }^{2-}\right)$ yang siap diserap oleh tanaman untuk mendukung pembentukan polong kedelai (Han \& Lee, 2005).

Rata-rata persentase bunga jadi polong berkisar antara 63,77-82,96\%. Persentase tersebut cukup tinggi karena jumlah bunga yang mengalami gugur hanya $40 \%$ yang paling banyak dari jumlah total bunga yang terbentuk. Menurut Suyamto \& Musalamah (2010) menyatakan bahwa tanaman berpolong menghasilkan bunga dalam jumlah yang banyak, namun bunga yang gugur berkisar antara 40-80\%. Selain itu, keberadaan bakteri Rhizobium yang bersimbiosis dengan tanaman kedelai diketahui mampu menambat nitrogen di udara. Menurut Zahran (2009) sekitar 80\% tersedianya nitrogen pada tanaman legume terjadi karena bersimbiosis dengan bakteri Rhizobium. Semakin banyak nitrogen yang difiksasi oleh bakteri Rhizobium dapat meningkatkan jumlah polong tanaman kedelai (Marlina et al., 2015).

\section{Bobot Polong}

Parameter bobot polong tanaman kedelai memperlihatkan hasil yang berbeda nyata antar perlakuan pemberian pupuk hayati VP3 dan pupuk hayati yang beredar dipasaran (Tabel 9). Perlakuan TKPH2 (Tanah + Kompos + Pupuk Hayati Sumber Subur) memberikan hasil yang lebih baik, namun tidak berbeda nyata dengan perlakuan TKHA (Tanah + Kompos + Pupuk Hayati VP3), TKPH3 (Tanah + Kompos + Pupuk Hayati Semanggi), dan TKPH4 (Tanah + Kompos + Pupuk Hayati Magicgro G6). Hal ini karena pupuk hayati yang diaplikasikan mengandung bakteri pelarut fosfat, salah satunya adalah bakteri Pantoea ananatis yang terkandung dalam pupuk hayati VP3 dan kemudian bakteri tersebut memanfaatkan keberadaan kompos sebagai sumber energi untuk kebutuhan hidupnya. Bakteri pelarut fosfat dapat meningkatkan ketersediaan $\mathrm{P}$ di dalam tanah melalui pelepasan asam-asam organik hasil metabolisme sel. Selain itu, bakteri pelarut fosfat juga mampu mensekresikan hormon pertumbuhan tanaman yang memacu pertumbuhan akar sehingga meningkatkan efisiensi penyerapan unsur hara $P$ (Oteino, et al., 2015.). 
Tabel 9. Rata-rata bobot polong tanaman kedelai pada perlakuan pupuk hayati VP3 dan pupuk hayati yang beredar dipasaran

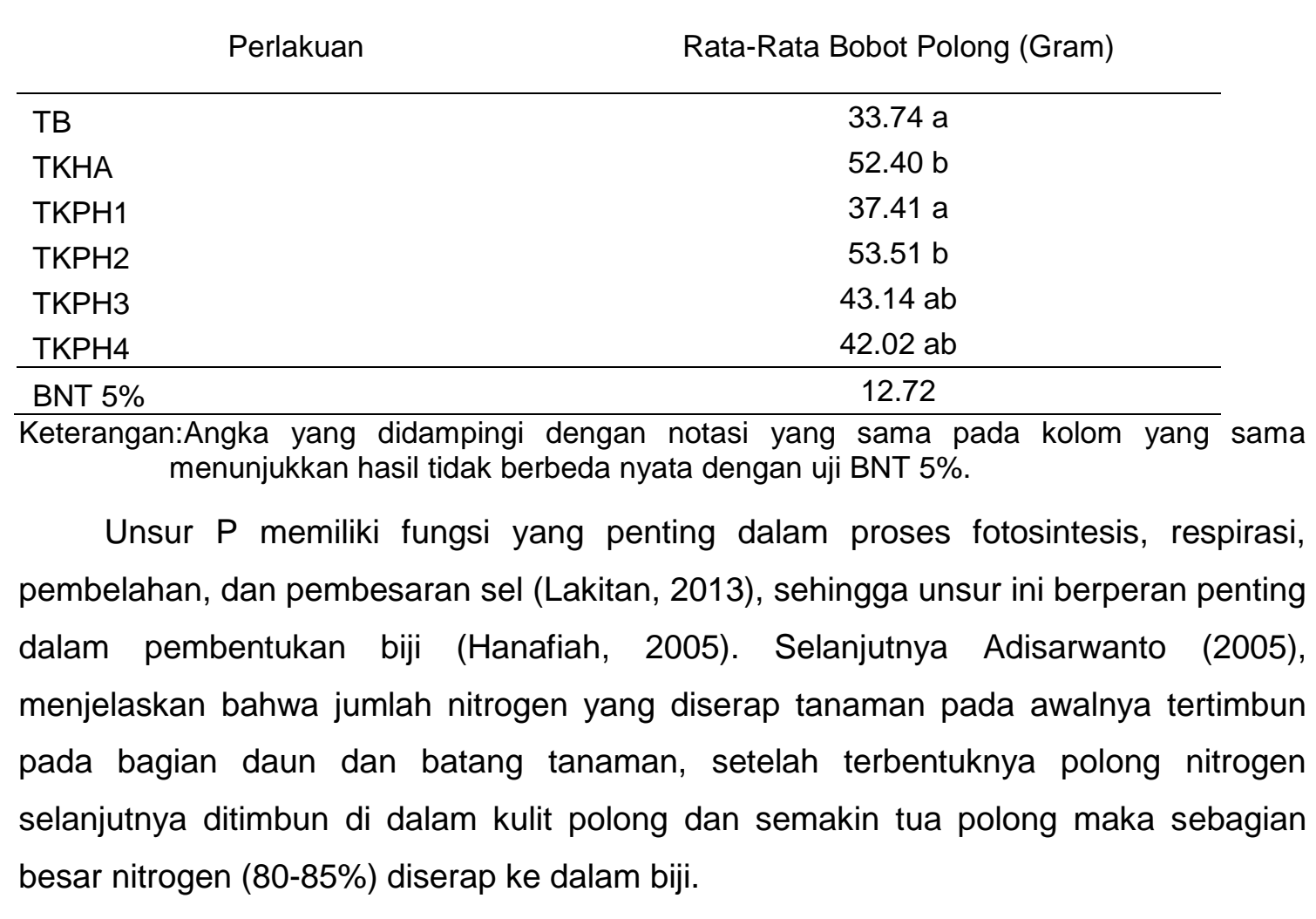

\section{Bobot Biji}

Hasil penelitian (Tabel 10) menunjukkan bahwa aplikasi pupuk hayati VP3 dan pupuk hayati yang beredar dipasaran tidak berpengaruh nyata terhadap bobot 100 biji, namun berpengaruh nyata terhadap bobot biji total per tanaman dan bobot biji total per petak.

Pada bobot 100 biji tanaman kedelai memberikan hasil yang sama antar perlakuan. Hal ini karena bobt 100 biji berkaitan dengan ukuran biji, dimana ukuran biji ini sangat dipengaruhi oelh faktor genetik. Sebagaimana dijelaskan oleh Pieter \& Mejaya (2018), bahwa pertumbuhan tanaman yang tampak (fenotip) dipengaruhi oleh faktor genetik dan lingkungan. Sehingga hal inilah yang menyebabkan pertumbuhan tanaman kedelai memiliki keseragaman pada bobot biji tanaman kedelai.

Pada bobot biji total per tanaman dan bobot biji total per petak menunjukkan hasil yang berbeda nyata antar perlakuan, namuperlakuan pupuk hayati VP3 dan pupuk hayati yang beredar dipasaran tidak berbeda nyata. Hal ini menunjukkan bahwa pupuk hayati VP3 lebih baik, karena mampu memberikan hasil yang sama dengan perlakuan pupuk hayati yang beredar dipasaran. Hal ini didasarkan pada pupuk hayati VP3 yang mengandung 3 bakteri tanah indigenous dengan bahan pembawa vermiwash, sedangkan pada pupuk hayati yang beredar dipasaran selain mengandung 
bakteri penambat hara tertentu juga mengandung unsur hara dan hormon bagi tanaman. Dengan demikian pupuk hayati VP3 dapat mengimbangi hasil dari perlakuan pupuk hayati yang beredar dipasaran.

Tabel 10.Rata-rata bobot 100 biji, bobot biji total per tanaman, dan bobot biji total per petak tanaman kedelai pada perlakuan pupuk hayati VP3 dan pupuk hayati yang beredar dipasaran

\begin{tabular}{cccc}
\hline \multirow{2}{*}{ Perlakaun } & \multicolumn{3}{c}{ Rata-rata bobot biji (gram) } \\
\cline { 2 - 4 } & $100 \mathrm{Biji}$ & Total Per Tanaman & Total Per Petak \\
\hline TB & 16.85 & $19.74 \mathrm{a}$ & $132.26 \mathrm{a}$ \\
TKHA & 16.35 & $23.98 \mathrm{bc}$ & $164.33 \mathrm{bc}$ \\
TKPH1 & 16.18 & $23.35 \mathrm{~b}$ & $157.08 \mathrm{~b}$ \\
TKPH2 & 16.27 & $23.31 \mathrm{~b}$ & $154.23 \mathrm{~b}$ \\
TKPH3 & 16.54 & $22.68 \mathrm{~b}$ & $149.27 \mathrm{~b}$ \\
TKPH4 & 17.01 & $26.44 \mathrm{c}$ & $177.03 \mathrm{c}$ \\
\hline
\end{tabular}

BNT 5\%

TN 2.91
15.63

Keterangan:Angka yang didampingi dengan notasi yang sama pada kolom yang sama menunjukkan hasil tidak berbeda nyata dengan uji BNT 5\%.

Secara umum, tinggi rendahnya hasil suatu tanaman dapat dipengaruhi oleh organ vegetatif tanaman salah satunya adalah daun. Tanaman kedelai dengan luas daun yang lebar akan menghasilkan asimilat yang banyak pula yang dapat digunakan untuk pertumbuhan generatif dengan menghasilkan bunga yang lebih banyak (Sutopo, 2019). Jumlah biji dapat ditingkatkan dengan peningkatan hasil fotosintat yang dihasilkan pada saat berbunga dan pembentukan polong agar fotosintat dapat dialokasikan pada biji (Van Roekel \& Salmeron, 2015). Semakin banyak biji yang terbentuk maka bobot biji yang dihasilkan semakin tinggi. Hal ini dikarenakan hasil fotosintesis pada fase vegetatif ke generatif disimpan sebagai cadangan makanan dalam bentuk karbohidrat yang berupa biji. Tingginya fotosintat yang dihasilkan maka akan meningkatkan hasil biji.

\section{Kesimpulan dan Saran}

Aplikasi pupuk hayati VP3 bila dibandingkan dengan pupuk hayati yang beredar dipasaran secara umum memberikan hasil yang lebih baik terhadap parameter pertumbuhan dan produksi tanaman kedelai di lapang. Hal ini ditunjukkan pada hasil signifikan pada pertumbuhan luas daun per tanaman dan pada pengamatan produksi bobot biji total per petak tanaman kedelai. Akan tetapi pemberian pupuk hayati VP3 terhadap potensi produksi tanaman kedelai varietas Anjasmoro masih rendah, dikarenakan musim tanam yang tidak tepat dan perawatan yang kurang intensif. 
Dari hasil penelitian ini disarankan untuk dilakukan penelitian lebih lanjut mengenai analisis bakteri tanah sebelum dan sesudah aplikasi pupuk hayati. Sebaiknya budidaya tanaman kedelai dilakukan pada musim tanam yang tepat.

\section{Daftar Pustaka}

Adisarwanto. 2005. Kedelai. Penebar Swadaya. Jakarta.

Apriliani, I.N., Heddy, S., dan Suminarti, N. E. 2016. Pengaruh kalium pada pertumbuhan dan hasil dua varietas tanaman ubi jalar (Ipomea batatas (L.) Lamb). Jurnal Produksi Tanaman, 4(4): 264-270.

Arfarita, N., Hidayati, N., Rosyidah, A., Machfudz, M. and Higuchi, T. 2016. Exploration of indigenous soil bacteria producing-exopolysaccharides for stabilizing of aggregates land potential as biofertilizer. Journal of Degraded and Mining Lands Management, 4(1): 697-702, doi: 10.15243/jdmlm.2016.041.697.

Arfarita, N., Lestari M.W., \& Prayogo, C. 2020. Utilization of vermiwash for the production of liquid biofertilizers and its effect on viability of inoculant bacteria and green bean germination. Journal of Agricultural Science, 42(1): 120-130, do: 10.17503/agrivita.v42i1.2263.

Arfarita, N., Lestari, M.W., Murwani, I. and Higuchi, T. 2017. Isolation of indigenous phosphate solubilizing bacteria from green bean rhizospheres. Journal of Degraded and Mining Lands Management, 4(3): 845-851, doi: 10.15243/jdmlm.2017.043.845.

Arfarita, N., Muhibuddin, A., and Imai, T. 2019. Exploration of indigenous free nitrogenfixing bacteria from rhizosphere of vigna radiata for agricultural land treatment. Journal of Degraded and Mining Lands Management, 6(2): 1617-1623, doi: 10.15243/jdmlm.2019.062.1617.

Bachtiar, B., Ghulamahdi, M., Melati, M., Guntari, D., dan Sutandi, A. 2016. Kebutuhan nitrogen tanaman kedelai pada tanah mineral dan mineral bergambut dengan budi daya jenuh air. Jurnal Penelitian Pertanian Tanaman Pangan, 35(3), 124293.

Eviati, S dan Sulaeman. 2009. Petunjuk Teknis Analisis Kimia Tanah, Tanaman, Air dan Pupuk Edisi ke-2. Balai Penelitian Tanah. Bogor.

Fadiluddin, M. 2009. Efek Formula Pupuk Hayati dalam Memacu Serapan Hara, Produksi, dan Kualitas Hasil Jagung Dan Padi Gogo Di Lapang. Tesis. Institut Pertanian Bogor. Bogor.

Farianti, N.L.I., Herlina, N., dan Haryono, D. 2018. Pengaruh pemberian kalium nitrat $\left(\mathrm{KNO}_{3}\right)$ terhadap pengisian biji tiga varietas tanaman keedelai (Glycine max (L.) Merrill). Jurnal Produksi Tanaman, 5(7): 1110-1118.

Zahran, H. H. 2009. Enhancement of Rhizobia-Legumes symbioses and nitrogen fixation for crops produvtivity improvement. In Microbial Strategies for Crop Improvement, 28(11): 227-254, doi: 10.1007/978-3-642-01979-1_11.

Han, HS. Supanjani, and Lee, KD. 2005. Effect of coinoculation with phosphate and potassium solublizing bacteria on mineral uptake and growth of pepper and cucumber. Plant Soil and Environment., 3: 130-136, doi: 10.17221/3356-PSE.

Hanafiah, K.A. 2005. Dasar-dasar IImu Tanah. Rajawali Pers. Jakarta.

Herdiyanto, D. dan Setiawan, A. 2015. Upaya peningkatan kualitas tanah melalui sosialisasi pupuk hayati, pupuk organik, dan olah tanah konservasi di Desa 
Sukamanah dan Desa Nanggerang Kecamatan Cigalontang Kabupaten Tasik Malaya. Jurnal Aplikasi Ipteks untuk Masyarakat, 4(1): 47-53.

Husen, E., Simanungkalit, Saraswati, R., dan Irawan. 2007. Characterization and quality assessment of indonesian commercial biofertilizers. Indonesian Journal of Agricultural Science, 8(1): 31-38, doi: 10.21082/ijas.v8n1.2007.p31-38.

Islam, M. R., Rahman, S. M. E., Rahman, M. M., Oh, D. H., and Ra, C. S. 2010. The effects of biogas slurry on the production and quality of maize fodder. Turkish Journal of Agriculture and Forestry, 34(1), 91-99.

Kartikawati, A., Trisilawati, O., dan Darwati, I. 2017. Pemanfaatan Pupuk Hayati (Biofertilizer) pada Tanaman Rempah dan Obat. Perspektif, 16(1): 33-43.

Lakitan, B. 2013. Dasar-Dasar Fisiologi Tumbuhan. Rajawali Pers. Jakarta.

Marlina, E., Anom, E., dan Yoseva. 2015. Pengaruh pemberian pupuk npk organik terhadap pertumbuhan dan produksi kedelai (Glycine max (L.) Merril). Jom Faperta, 2(1): 1-13.

Maryani, A. T. 2012. Pengaruh volume pemberian air terhadap pertumbuhan bibit kepala sawit di pembibitan utama. Fakultas Pertanian. Jurnal Universitas Jambi, 1(2): 64-74.

Mawardiana, Sufardi, dan Husen, E. 2013. Pengaruh residu biochar dan pemupukan NPK terhadap dinamika nitrogen, sifat kimia tanah dan hasil tanaman padi (Oryza sativa L.) musim tanam ketiga. Jurnal Manajemen Sumber Daya Lahan, 2(3): 255-260.

Novriani. 2011. Peranan Rhizobium dalam meningkatkan ketersediaan nitrogen bagi tanaman kedelai. Jurnal Agronobis, 3(5): 35-42.

Nugrayasa, O. 2013. Problematika Harga Kedelai. Online. www.setkab.go.id. Diakses 31 Juni 2019.

Ohyama, T., Tewari K., Shinji I., Kazuya T., Satoshi K., Yuki O., Soshi H., Norikuni O., Kuni S., Hideo H., Takashi S., Sayuri T., Yoshifumi N., Yoichi F., \& Yoshihiko T. 2017. Role of nitrogen on growth and seed yield of soybean and a new fertilization technique to promote nitrogen fixation and seed yield. in soybean-the basis of yield, biomass and productivity. InTech. 153-185, doi: 10.5772/66743.

Oteino, N., R.D. Lally, S. Kiwanuka, A. Lloyd, D. Ryan, K.J. Germaine and D. N. Dowling. 2015. Plant growth promotion induced by phosphate solublizing endophytic pseudomonas isolates. Frontiers in Microbiology, 6:1-9, doi: 10.3389/fmicb/2015.00745.

Pieter, Y., dan Mejaya, M. J. 2018. Produksi tiga varietas kedelai akibat aplikasi pupuk hayati. Jurnal Penelitian Pertanian Tanaman Pangan, 2(1), 51-57.

Roidah, I.S. 2013. Manfaat Penggunaan Pupuk Organik untuk Kesuburan Tanah. Jurnal Universitas Tulungagung Bonorowo, 1(1): 30-42.

Sutopo, A. 2019. Pengaruh naungan terhadap beberapa karakter morfologi dan fisiologi pada varietas kedelai ceneng. Jurnal Citra Widya Edukasi, 11(1): 131142.

Suyamto, S., dan Musalamah, M. 2010. kemampuan berbunga, tingkat keguguran bunga, dan potensi hasil beberapa varietas kedelai. Buletin Plasma Nutfah, 16: 38-43, doi: 10.21082/blpn.v16n1.2010.p38-43. 
Tania, N., dan Budi, S. 2012. Pengaruh pemberian pupuk hayati terhadap pertumbuhan dan hasil jagung semi pada tanah podsolik merah kuning. Jurnal Sains Mahasiswa Pertanian, 1(1): 10-15.

Van Roekel, R.J., L.C. Purcell and M. Salmeron. 2015. Physiological and management factors contributing to soybean potential yield. Field Crop Research, 182(2015): 86-97, doi: 10.1016/j.fcr.2015.05.018. 